\title{
THE SOCIAL CONSTRUCTION OF ENVIRONMENT IN LATVIAN LOCAL NEWSPAPERS
}

\author{
Ianis Bucholtz ${ }^{\prime \prime}$ Dr. Sc. comm. \\ ${ }^{1}$ Institute of Social, Economic and Humanities Research of Vidzeme University of Applied Sciences
}

\begin{abstract}
This paper examines the content of four local Latvian newspapers in order to find out how the media construct the environment of four inhabited places - Mazsalaca, Kandava, Kraslava, and Kemeri. The analysis of newspapers "Liesma," "Neatkarigas Tukuma zinas," "Ezerzeme," and "Jurmalas vards" show that during the last six months of 2017, the most prominent themes that describe local landscapes were nature and ecology, agriculture, social environment, people, surroundings, and events, belonging and identity, and borders. While the newspapers differ in the attention they pay to some themes, the dominating meanings attached to the places they cover share similarities. The newspapers acknowledge the social and economic challenges of the inhabited places they cover, but at the same time, they emphasise what they interpret as unique qualities of the place, such as nature, people, and cultural heritage. Thus, the analysis shows how media, through negotiating and enforcing meanings of physical environments, take part in shaping local landscapes, which emerge as culturally grounded symbolic expressions recognized by the local communities.
\end{abstract}

Key words: landscapes, Latvian municipalities, local media, local newspapers, social construction of environment.

JEL code: B54

\section{Introduction}

Since in the contemporary advanced societies nearly everything people know they know from the media (Luhman, 2000), media takes a central role in communication processes. This refers not only to transmission of information, but also maintaining social and interpersonal connections among people, institutions, and places. As noted by Akhil Gupta and James Ferguson (1997), mediated experience is an integral part of even the most local experiences.

Alongside with geographical and administrative divisions and public institutions, the media take part in shaping spatial and social territories (Zelce, 2006). The contemporary information environment is characterized by increased supply of sources and subsequent fragmentation of audiences (Jenkins, 2006; Rozukalne, 2012), but local media, which report on topicalities in a particular populated area, still are important providers of information and viewpoints. Despite globalization, life of the majority of people is still locally grounded, and many of their important relationships take place in their local area (Aldridge, 2007). On the one hand, the local media are agents that socially construct (Berger and Luckmann, 1971) the particular place. On the other hand, the media themselves are a product of place-based relationships in which they operate. Their unique place in the local information environment invite inquiry into how they present and interpret the places they are covering.

The aim of this paper is to examine landscapes that Latvian local newspapers present through their coverage of four distinct inhabited places. Thomas Greider and Lorraine Garkovich (1994) define "landscape" as a "symbolic environment created by a human act of conferring meaning on nature and the environment." In other words, landscapes refer to social constructions of physical environments that are perceived and described through the lens of particular values and beliefs. This concept relates to David Morley's (2000: 174) description of "place" as "the materialized idea of the relations that its inhabitants have with each other, with their ancestors and with outsiders." Thus, people who live or frequent a particular place, incorporate their ties to it within their networks of connections to their peers, histories, and social norms. Various social groups can interpret the same environment quite differently and attach different meanings to it. 
In this case, the elements through which environments are presented in the local newspapers illustrate some of the meanings that are negotiated and enforced through the media discourses, which, in turn, at least partly shape and are shaped by the conceptions present in the local audience.

\section{Local newspapers in Latvia}

Most of the current Latvian local newspapers can trace their roots back to the Soviet times, when a newspaper was issued in each administrative district (Zelce, 2006). Even though the founding rationale for the existence of local newspapers in the Soviet times was an ideological one - their objective was to communicate the official narratives to the public - , these newspapers managed to become an intrinsic and beloved part of the daily lives of the local population. In addition to their standardized political functions, the local print media also promoted and communicated local symbols, self-conceptions, and emotional environments that distinguish the particular populated area from other territories (Zelce, 2006). In doing so, these newspapers have had a role in defining, shaping and acknowledging local communities as distinct social entities.

Currently, the circulations and, by extension, turnover of Latvian newspapers are in steady decline (Brikse and Zelce, 2008). This process was particularly exacerbated by the consequences of the global economic crisis of 2008 (Spakovska, Jemberga, Krutaine and Springe, 2014). National newspapers lose in competition with online sites that provide news for free and are updated constantly. The withering of readership has also been an issue for local newspapers. Diminishing local populations, fall of advertising revenues and free-of-charge municipal newsletters, which distort competition (Cepkauskaite, Krutaine, Matsalu and Spakovska, 2015), pose long-term risks to the survival of the local newspapers. According to Guntars Licis, the managing director of the Latvian Association of Press Publishers, most of the Latvian local media currently are balancing on the edge of survival, and many such newspapers are not profitable (Balode, 2017). The online versions of the local newspapers usually do not make money.

At the same time, the local newspapers up until now have been a little more resistant to the processes that have caused the decline of national newspapers. Few local online-based competitors to the newspapers exist, and these print outlets in many cases preserve their niche in the market. In $2017,31 \%$ of the Latvian population had read or skimmed though at least one local newspaper per week (TNS Latvia, 2017). Thus, study of these newspapers still provides some insight into the local public spaces that are shaped by the media and, through them, perceived by the audience.

Vita Zelce (2006) previously has reported that the most prominent topics in the Latvian local newspapers are cultural events, everyday life, and politics; less attention is reportedly being devoted to the economy. Municipal public relations newsletters, in turn, have been shown to present environment-related issues through such themes as nature, cultural and historical heritage, safety, and quality of life, while abstaining from the critical evaluation of the performance of municipal officials (Bucholtz, 2017). However, journalistic entities are guided by media logic that differs from other media production disciplines (Deuze, 2009), thus the contents of two types of media outlets are not necessarily comparable.

\section{Methodology}

The data was gathered from the newspapers that cover four municipalities in Latvia: Mazsalaca, Kraslava Kandava, and Kemeri. These territories were chosen based on their diversity from each 
other in terms of size, population, location, and available natural and cultural resources. These territories are the focus of a research project "The processes of the development of cultural environment, preservation of environmental diversity and urbanization in the context of balanced development of Latvia," which examines balanced regional development through the lens of cultural environment, environmental diversity, and urbanization processes (Livina et al., 2016).

Mazsalaca (territory: 417 square kilometres; population: 3 030) (CSB, 2017) is a small town in the northeast part of Latvia and is a quite popular destination for tourists largely thanks to its nature trail. Events in Mazsalaca are covered by "Liesma," a newspaper that particularly focuses on Valmiera, which is the largest city of the region, and is issued four times a week. Kraslava (territory: 1079 square kilometres; population: 14 963) (CSB, 2017) is located in the southeast part of Latvia, which is a region with a distinct cultural and geographical peculiarity. Kraslava is one of the municipalities covered by "Ezerzeme," which is issued twice a week in Latvian and Russian. Kandava (territory: 649 square kilometres; population: 8 085) (CSB, 2017) is a town in the western part of Latvia that lies within the Abava valley, which refers to a cultural and historical entity. The local newspaper that reports on topicalities in Kandava is "Neatkarigas Tukuma zinas." It is issued three times a week. Lastly, Kemeri (territory: 13.8 square kilometres; population: 2288 ) is a part of Jurmala, one of the larger cities in Latvia. Historically Kemeri has been associated with its resort and mineral springs. Kemeri is also notable for a national park with a popular bog trail. Events in Kemeri are covered by "Jurmalas vards," which comes out once per week in Latvian and Russian.

The study covers a period of the last six months of the year 2017. The output frequency of the analysed newspapers varies, so the first issue of each week was included in the sample, thus ensuring that each newspaper has an equal number of issues reviewed. The exception was made regarding "Liesma," of which the Thursday, rather than Tuesday issues were reviewed. On Thursdays, it publishes a section dedicated to municipalities near Valmiera.

The method employed in the study is the thematic analysis, which is suitable for the identification and examination of themes and concepts in various texts. It takes its approach from the grounded theory (Glaser and Strauss, 2006), which ascribes identifying analytical categories directly based on data, rather than pre-defined theoretical frameworks.

The procedure was based upon the principles of open coding (Bohm, 2004) and went as follows. The author read every article in the selected newspapers that discussed the particular place (Mazsalaca in "Liesma", Kraslava in "Ezerzeme" and so on) in order to get a sense of what is being reported and in what way; what aspects, events and objects are being highlighted, and who the described people are. Based on these observations, the author developed codes that capture the topics, actors, tones of expression, and other peculiarities that emerged. Finally, the findings were contextualized and the patterns interpreted as illustrations of the local landscapes.

\section{Results}

Nature and ecology, agriculture, social environment, people, surroundings and events, belonging and identity, and borders are among the most prominent themes that describe the local landscapes in the newspapers. This section describes each of these themes in detail.

Nature. The general focus of the newspaper coverage is on urban aspects of life and processes that have a short-term influence on the lives of local population. Since during the period of analysis no serious natural disasters, ecological hazards or other easy-to-report events occurred in the four 
places, these topics, with some exceptions, apparently did not possess a significantly large news value.

The discussions of nature more commonly appear in discussions of the qualities that make the populated place attractive. For example, the chair of Kandava Municipality Inga Priede is reported as saying that "one of the benefits the municipality can offer to people that might move to the county is the beautiful nature" (Plaude and Trede, 2017). Similarly, the inhabitants of Mazsalaca reportedly claim that the vicinity to nature is a key reason why they find this to be "the best place to live" (Kalnina, 2017a).

In the coverage of "Jurmalas vards," nature was a political issue. The deputies of Jurmala City Council had opposing views about the plans to build new electrical lines that would cross a part of Kemeri National Park. Some fear that these electrical lines not only will ruin the aesthetics of the landscape, but also that the planned earthworks might disturb the local geology and damage the mineral springs of Kemeri. Others think that the availability of additional electrical power capacity is necessary for the further development of the territory. "The deputy from Nacionala apvieniba [the National Alliance] Andris Cuda takes a stand against the Kemeri National Park and the core values of the resort town - curative springs," the paper said of a politician who supported the building of the new power lines (Vilnitis, 2017).

Agriculture. Since agriculture of one of the traditionally strong economic sectors in the regions of Latvia, this topic is quite visible in the newspaper contents. A staple of news coverage in autumn is reports of harvesting crops and preparing agricultural fields for the next season. Association with agriculture holds a special place in the Latvian national identity (Locmele, 2014). While culturally rooted sympathies towards farmers in the newspapers can be encountered in the newspaper coverage, these are mostly implicit - agriculture is predominantly presented from the economy perspective. The reports on successes and failures of the agricultural sector, by extension, also contribute to the depiction of the prospects of providing jobs and attracting inhabitants to the place. The newspapers present farmers as mostly prosperous entrepreneurs who contribute to the general development of the place. For example, "Liesma" reported the growth in a local farm and noted its new grain dryer (Kalnina, 2017b), "Ezerzeme" stated that the participants in a seminar for growers of rapeseed and cereals have expressed hopes for a good harvest, barring adverse weather conditions (Goncarovs, 2017a). An exception is Kemeri, in which recreation and wellness industry, rather than agriculture, is among the most important resources of the local economy. As such, reports on the topicalities of resort and spa industry can be regularly encountered in the coverage of Kemeri in "Jurmalas vards."

Social environment. The reflections on living conditions and opportunities in the local newspapers are two-fold. On the one hand, usually the newspapers favourably depict their towns and municipalities and describe the various qualities of these particular places, including cultural events, a forthcoming local population, and generally pleasurable living conditions. These qualities routinely are expressed as general attitudes by the interviewed locals (e.g., Kalnina, 2017c) or can be encountered in the reports on various events or developments, such as town festivals (Balandina, 2017; Kalnina, 2017d), sports and health events (Ezerzeme, 2017; Trede, 2017a), or reconstructions of public infrastructure (Liesma, 2017; Jurmalas vards, 2017). On the other hand, the newspapers are not oblivious to the fact that many towns and villages in Latvia experience depopulation and other social and economic long-term challenges. "Liesma" in particular has stressed the lack of jobs in Mazsalaca (e.g., Kalnina, 2017b); other media also have acknowledged 
a substantial loss of the local population during the last decades. Moreover, since none of the analysed places is a regional centre, the sense of periphery is evident in references to sub-optimal public transport schedules (Kalnina, 2017b) and the unavailability of banking (Plaude and Trede, 2017) or other services.

Thus, the depiction of the social environment has to accommodate these two experiences, which are in conflict with one another. Usually this is achieved by avoiding the mentioning of problems in articles that praise the local environment or by stressing that the locals appreciate their town despite some hardships - or that they are doing something about them. For example, "Liesma" reports that the local inhabitants of Mazsalaca are developing new sources of revenue and becoming entrepreneurs (Kalnina, 2017e). Overall, the newspapers are more appreciative than critical of the places they cover. The criticism commonly is about particular details of the local environment - from the lack of benches near houses (Trede, 2017b) to handling hooliganism (Nipane, 2017), to unemployment (Kalnina, 2017a). Conversely, the praise is aimed at the enjoyable and unique characteristics of the place (such as nature and cultural heritage) and the opportunities it offers.

"Human beings are seen as living in a world of meaningful objects," states Herbert Blumler (1966: 540). "Different groups come to develop different worlds - and these worlds change as the objects that compose them change in meaning." In their interpretation of Herbert Blumer's ideas, Greider and Garkovich (1994) stressed that it is not the change of the physical environment that causes changes in how groups see their landscapes. The change is driven by the shift of meanings a group attaches to these transformations. In the case of the studied newspapers, they take notice of various local problems and unwelcome changes, but do not interpret them as undermining the core qualities of the particular places.

People, surroundings and events. Depictions of the local landscapes require local people within their institutional or infrastructural surroundings. Schools, cultural centres, libraries, parks, and open-air leisure areas are among the commonly presented territories against the backdrop of which various activities are being described. Schools are mentioned not only in the context of education opportunities of young people, but also as places where various cultural, learning, and sports events for much wider public are held. For example, in the stadium of the Kemeri primary school, the national combined competition for dogs took place (Pavlovskis, 2017), and in Kraslava, the school is said to host Latvian-Polish culture events (Goncarovs, 2017b). Teachers as key culture workers of the covered places and students' achievements also are common topics of the articles.

The various annual festivals are among the most widely covered topics that are virtually universal in the analysed newspapers. Through these festivals, as well as the events with participation of local and national level activists or culture workers - authors, actors, entrepreneurs, benefactors - , the newspapers depict at least somewhat vibrant social life that is interesting not only to the local public but also to guests from elsewhere.

Notable social groups are young people and seniors. The attention they achieve in the newspapers probably at least partly depends on the activities of respective organizations themselves and the attention they manage to attract. Thus, "Neatkarigas Tukuma zinas" regularly reports on the activities and events organized by youth centre "Nagla" (e.g., Trede, 2017d; Trede, 2017e), while "Ezerzeme" has informed about the "The school of seniors" (Azamatova, 2017) - a free training program for retired people. 
The newspapers vary greatly in their coverage of the municipal councils. "Neatkarigas Tukuma zinas" reports in detail the topics discussed during the sessions of the council and occasionally interviews the local officials. "Ezerzeme" writes about the meetings between the chair of the council and the inhabitants of Kraslava, although it generally pays relatively small attention to the activities of the workings of the municipal offices. "Jurmalas vards" takes notice of the political divisions within the council, which arguably are much more pronounced than in other studied municipalities, and puts larger emphasis on naming and depicting the local politicians. "Liesma," on the contrary, pays small attention to the agenda of the municipal council of Mazsalaca. Thus, rather than watching or, worse, serving the local officials, some papers distance themselves from the decision-making processes that shape other processes these media subsequently report on.

Belonging and identity. The local newspapers communicate affection of the geographical territories they cover. The articles that contain favourable statements about the place, which usually are expressed through the quotes of the interviewed people, are the clearest examples of shaping the meanings that media attach to the environment. The affection stems from a long-term connection with the place, rather than a detached assessment of the prospects, resources, or deficiencies. For example, "Neatkarigas Tukuma zinas" relays what it calls a commonly held view among participants of a certain event: "... people are proud of the place they come from (in this case - in Kandava), they take pleasure in doing their job, but sometimes underestimate their contributions." (Trede, 2017f). In one publication, "Liesma" states that some families of Mazsalaca "have been taking root here for centuries" (Kalnina, 2017f).

Additionally, the newspapers stress the importance of the local history and cultural heritage. In Kemeri, this is expressed through somewhat nostalgic acknowledgement that its curative industry has yet to match its past glory, and at least until now, the plans of its redevelopment have been coming to life quite slowly (e.g., Zinu dienests, 2017a). Historical buildings, such as a manor (Kalnina, 2017f) and a church (Jakubovskis, 2017), and local legends and folklore characters, for example, the one about the devil/trickster (Kalnina, 2017g), are among the highlighted local peculiarities.

Although praises to the qualities of the place are present in all analysed newspapers, "Ezerzeme" stands out with its at times amusingly excited descriptions of Kraslava. For example, "The second Switzerland, the pearl of Latgale, a town by the Curves of Daugava... All these highsounding and lyrical lines describe our beloved Kraslava. And is it not that this touching name has derived from the word "beauty" ("krasa" in Russian)?" (Goncarovs, 2017c).

Borders. Each delineated territory inevitably has borders that separate the area from the rest of the country and the world. The analysed newspapers cover events and topicalities of multiple adjacent administrative territories, which form and reinforce the sense of them as distinct social and geographical entities. Thus, the people who read "Neatkarigas Tukuma zinas" are likely to see Tukums, Kandava, Engure, and Jaunpils municipalities as belonging together, so does the readers of "Liesma", which addresses the inhabitants of Valmiera, Rujiena, and Mazsalaca.

The examined newspapers vary in the degree to which they incorporate "outside" territories in their coverage. One approach is the inclusion of some national and even international news and perspectives in their coverage - for example, political commentaries and travel features. Another approach is to highlight the qualities of the place that makes it stand out in the national or even international context. For example, Mazsalaca hospital reportedly was among the first medical facilities in Latvia to develop specialization in palliative care (Kalnina, 2017h) and has the popular 
Skanaiskalns nature trail (Kalnina, 2017i), while the resort and rehabilitation centre "Jaunkemeri" still enjoys the good reputation (Zinu dienests, 2017b) it developed during the Soviet times and attracts clients not only from Latvia, but also from other, particularly CIS, countries. Still, the prevalence of local topicalities, attention given to the local territories, and orientation towards the local population that can be expected in such media outlets maintain an "us" and "them" construction in which each party at the opposing sides of the border is belong to different inhabited places and social groups.

Particularly notable counter-examples can be found in "Ezerzeme," which, while acknowledging the regional peculiarity of Kraslava, simultaneously stresses the ethnic and cultural diversity (Leikuma, 2017) that historically characterizes the Latgale region of Latvia. The newspaper also pays more attention to the development of international ties of various kinds, including friendships with people from other countries (Zdanovska, 2017) and cross-border cooperation between local level institutions (Goncarovs, 2017d).

\section{Conclusions}

Through the analysis of the most prominent elements that describe the four populated places in Latvia, this paper has examined the themes through which the local media present the local landscapes. This section lists the main takeaways from this study.

1) The interpretations of the dominant topics in the examined newspapers present a positive concept of the places. Even though the media mention a variety of long-term challenges, such as unemployment or depopulation, the publications generally focus on the elements that highlight local qualities, such as cultural life, historical heritage and other elements that in their eyes make the place valuable to the locals and interesting to its guests.

2) The sense of possible or even ongoing decline of the place is countered by describing qualities that are unavailable in other places. The media refer to the analysed places as beautiful, having a small town charm, and also having a development potential in the future. Subsequently, economic or social challenges per se do not necessarily determine how the media or the locals see their landscapes. In the analysed newspapers, acknowledgements of local problems are overwhelmed by the references of local qualities, which are said to be unavailable elsewhere, and the special relationship the local population has with the place.

3) The editorial choices, which contribute to the emergence of particular landscapes in the media content, are most evident in the differences of how certain topics are presented. One such topic is politics. "Neatkarigas Tukuma zinas" and "Jurmalas vards" pay considerable attention to the local politics and activities of municipal officials, even though their approaches to this topic have considerable differences. "Ezerzeme" and "Liesma," on the contrary, seem to be less interested in the inner workings of the Kraslava and Mazsalaca municipal council, respectively. At this point, we can only wonder whether the avoidance of particular themes is a deliberate approach some newspapers take to maintain their self-defined equilibrium between highlighting things that affect the quality of life in the particular place and maintaining the view on the place as special and attractive.

4) The analysed newspapers are more willing to discuss practical deficiencies of the place and suggest improvements than the official newsletters issued by most municipalities in Latvia, which are employed as public relations tools (Bucholtz, 2017). Thus, the local newspapers are more likely to fulfil the journalistic watchdog role more effectively. At the same time, these 
media outlets vary greatly in their willingness to probe the various social, economic, and political issues of the place, which, in the absence of media attention, may remain invisible to the local public.

5) The limited scope of the study does not allow for broader generalizations about the local mediated landscapes in Latvia. However, it has shown some similarities with and differences from the previous research on the contents of Latvian local media. Zelce (2006) noted that local newspapers in Latvia pay attention mostly to cultural events, everyday life, and politics, but economy-related themes are less prominent. The present study shows that culture and everyday activities indeed are among the most widely discussed. However, although local economy usually is not addressed directly - for example, thought the analysis of statistical data -, implicitly it is present within the important themes of depopulation, unemployment, entrepreneurship, and agriculture.

\section{Acknowledgements}

This work was supported by the project No. 5.2. of the Latvian National Research Program, "Economic Transformation, Smart Growth, Governance and Legal Framework for the State and Society for Sustainable Development - a New Approach to the Creation of a Sustainable Learning Community (Ekosoc-LV)" and is part of the sub-project No. 2.5.8, "The processes of the development of cultural environment, preservation of environmental diversity and urbanization in the context of balanced development of Latvia."

\section{Bibliography}

1. Aldridge, M. (2007). Understanding the Local Media. Maidenhead: Open University Press.

2. Balandina, A. (2017). Kemeru svetkiem negaisi met likumu (Thunders Bypass Kemeri Festival). Jurmalas vards, No. 31 (212), 2-3lpp,

3. Balode, L. (2017). Pasvaldibu informativie izdevumi un regionalie mediji. Strupcels (Municipal Bulletins and Regional Media. Dead End). LV portals "Par likumu un valsti". Retrieved: http://www.Ivportals.Iv/visi/likumiprakse/287181-pasvaldibu-informativie-izdevumi-un-regionalie-mediji-strupcels/ Access: 01.01.2018.

4. Berger, P. L., Luckmann, T. (1971). The Social Construction of Reality: A Treatise in the Sociology of Knowledge. New York: Anchor Books.

5. Blumer, H. (1966). Sociological Implications of the Thought of George Herbert Mead. American Journal of Sociology, Volume 71, Issue 5, pp. 535-544.

6. Bohm, A. (2009). Theoretical Coding: Text Analysis in Grounded Theory. In U. Flick, E. von Kardorff \& I. Steinke (Eds.), A Companion to Qualitative Research. London: Sage Publications, pp. 270-275.

7. Brikse, I., Zelce, V. (2008). The Latvian Media in the New Millennium: Trends in Development, Content and Usage and the Emergence of a Community of Media Users. Informacijos mokslai/Information Sciences, Volume 47, pp. 87-111. Retrieved: http://www.zurnalai.vu.It/files/journals/163/articles/3339/public/87111.pdf Access: 01.01.2018.

8. Bucholtz, I. (2017). Environmental Communication in Latvian Municipal Newsletters. In Environment. Technology. Resources: Proceedings of the 11th Scientific and Practical Conference, Vol. 1. Rezekne: Rezekne Academy of Technologies, pp. 46-50. Retrieved:

https://www.researchgate.net/publication/317604179 Access: 01.01.2018

9. Cepkauskaite, A., Krutaine, A., Matsalu, E., Spakovska, E. (2015). Baltic Media Health Check 2014-2015. Retrieved: http://www.sseriga.edu/files/content/baltic_media_health_check_2014-2015.pdf Access: 01.01.2018.

10. CSB (2017). Area, population density and resident population by statistical region, city and county. Central Statistical Bureau of Latvia. Retrieved: http://ej.uz/csb2017 Access: 01.01.2018.

11. Deuze, M. (2009). The Media Logic of Media Work. Journal of Media Sociology, Volume 1, Issues 1\&2, pp. 22-40.

12. Ezerzeme (2017). Veselibas svetku programma (The Schedule of Health Festival). Ezerzeme, No. 52 (9151). p. 2.

13. Glaser, B. G., Strauss, A. L. (2006). The Discovery of Grounded Theory: Strategies for Qualitative Research. New Brunswick: Aldine Transaction.

14. Goncarovs, A. (2017a). Diena laukos - lietaina, tacu vertiga un interesanta (A Day in Countryside - Rainy, but Valuable and Interesting). Ezerzeme, No. 54 (9153), p. 3. 
15. Goncarovs, A. (2017b). Polu regate jeb neparastas brivdienas (Polish Regatta or the Extraordinary Holidays). Ezerzeme, No. 64 (9163), p. 5.

16. Goncarovs, A. (2017c). Kad sapni piepildas (When Dreams Come True). Ezerzeme. No. 80 (9179), p. 1.

17. Goncarovs, A. (2017d). Pierobezas sadarbiba paplasinas (Cooperation in the Borser Area Widens). Ezerzeme, No. 90 (9189), p. 3.

18. Greider, T., Garkovich, L. (1994). Landscapes: The Social Construction of Nature and the Environment. Rural Sociology, Volume 59, Issue 1, pp. 1-24.

19. Gupta, A., Ferguson, J. (1997). Culture, Power, Place: Ethnography at the End of an Era. In A. Gupta \& J. Ferguson (Eds.), Culture, Power, Place: Explorations in Critical Anthropology. London: Duke University Press, pp. 1-32.

20. Jakubovskis, A. (2017). Sveta Ludviga baznicai 250 gadi: pirma diena (divas izstades un konference) (The 250th Anniversary of St. Ludwig' Church: The First Day (Two Exhibitions and a Conference). Ezerzeme, No. 50 (9149), pp. 1-3.

21. Jenkins, H. (2006). Convergence Culture: Where Old and New Media Collide. New York University Press: New York.

22. Jurmalas vards (2017). Iedzivotaji aicinati precizet pievadu izbuves vietas (Inhabitants are Asked to Report Where Inlets Should Be Built) Jurmalas vards, No. 46 (227), p. 2.

23. Kalnina, I. (2017a). Novada trukst darba vietu (The County Lacks Jobs). Liesma. Dzives vide Ziemelvidzeme - musu kopeja telpa, November 16, p. 1.

24. Kalnina, I. (2017b). Galvenais resurss ir zeme (The Main Resource is the Land). Liesma. Dzives vide Ziemelvidzeme - musu kopeja telpa, December 28, p. 3.

25. Kalnina, I. (2017c). Kada ir Mazsalaca un vietejie? (What is Mazsalaca and Its Population Like?) Liesma. Dzives vide Ziemelvidzeme - musu kopeja telpa, October 26, p. 3.

26. Kalnina, I. (2017d). Svetki Selu muiza (Festifal at the Seli Manor). Liesma, August 3, p. 6.

27. Kalnina, I. (2017e). Atradusi daramo (They Have Found Something to Do). Liesma. Dzives vide Ziemelvidzeme - musu kopeja telpa, December 28, p. 4.

28. Kalnina, I. (2017f). Mazpilseta sarme cauri gadsimtiem (The Small Town Charms throughout the Ages). Liesma. Dzives vide Ziemelvidzeme - musu kopeja telpa, October 26, p. 3

29. Kalnina, I. (2017g). Savadais velnu stasts (The Strange Story of Devils). Liesma. Dzives vide Ziemelvidzeme - musu kopeja telpa, October 26, p. 4.

30. Kalnina, I. (2017h). Iet pa attistibas celu (Going the Way of Development). Liesma. Dzives vide Ziemelvidzeme - musu kopeja telpa, December 7, p. 3

31. Kalnina, I. (2017i). Dabas milotaju tiksanss vieta (The Meeting Place for Nature Lovers). Liesma. Dzives vide Ziemelvidzeme - musu kopeja telpa, October 26, p. 4.

32. Leikuma, I. (2017). "Pi vina golda" ("At a shared table"). Ezerzeme, No. 96 (9195), p. 2, 4.

33. Liesma (2017). Parvads tiek parbuvets (Overpass is Being Reconstructed). Liesma, October 5, p. 6.

34. Livina, A., Veliverronena, L., Kruzmetra, Z., Grinfelde, I., Buholcs, J., Smalinskis, J., Vasile R. (2016). Kulturas mantojuma lietojums regionu lidzsvarota attistiba (The Use of Cultural Heritage in the Balanced Development of Regions). Latvijas Zinatnu akademijas vestis, A dala, Volume 70, Issue 3, pp. 91-101.

35. Locmele, K. (2014). Lauku diskurss prese latviesu valoda Latvija (1989-2012): Promocijas darbs (Rural discourse in the Latvian Language Press of Latvia (1989-2012): Doctoral thesis). Riga: Latvijas Universitates Socialo zinatnu fakultate. Retrieved: https://www.szf.lu.Iv/fileadmin/user_upload/szf_faili/Petnieciba/Locmele_Klinta_2014.pdf AccessL 01.01.2018.

36. Luhman, N. (2000). The Rality of Mass Media. Stanford: Stanford University Press.

37. Morley, D. (2000). Home Territories: Media, Mobility and Identity. London: Routledge,

38. Nipane, M. (2017). Iespeja aktualizet problemas (An Opportunity to Point out Issues). Ezerzeme, 82 (9181), p. 2.

39. Pavlovskis, I. (2017). Nacionalas sunu daudzcinas pasakums noriteja azartiski (National Event of Combined Dog Sports Was Venturous). Jurmalas vards, No. 31 (212), p. 3.

40. Plaude, I, Trede, L. (2017). Pec deviniem gadiem deputatos (After Nine Years of Being a Deputy). Neatkarigas Tukuma zinas, No. 118 (2591), pp. 4-5.

41. Rozukalne, A. (2012). Media Audience Development in Latvia (2004-2012). Media Transformations. Vol. 6, pp. $144-157$.

42. Spakovska, R., Jemberga, S., Krutaine, A., Springe, I. (2014). Is There Life After the Crisis? Analysis of the Baltic Media's Finances and Audiences (2008-2014). Retrieved: https://en.rebaltica.Iv/2014/11/estoniasmedia-are-healthiest-in-the-baltics/ Access: 01.01.2018.

43. TNS Latvia (2017). Nacionala preses auditorijas petijuma rezultati 2017. gada rudeni (The Results of the National Press Audience Study in the Autumn 2017). Kantar TNS. Retrieved: http://tns.Iv/?lang=Iv\&fullarticle=true\&category=showuid\&id=5202 Access: 01.01.2018.

44. Trede, L. (2017b). Bus nauda, bus solini (If There Will Be Money, There Will Also Be Benches). Neatkarigas Tukuma zinas, No. 148 (2621), p. 5.

45. Trede, L. (2017f). But savas dzives noteicejai (To Be the Master of One's Own Life). Neatkarigas Tukuma zinas. Laiks uznemejam, No. 124 (2597), p. 2. 
46. Trede, L. (2017d). Diskusijas par jauniesiem svarigam lietam (Discussions about Things Important to the Youth). Neatkarigas Tukuma zinas, No. 106 (2579), p. 5.

47. Trede, L. (2017e). Notiks jauniesu forums (Youth forum to be held). Neatkarigas Tukuma zinas, No. 151 (2624), p. 5.

48. Azamatova, T. (2017). Senioru skolas vasaras jaunumi (News from the Summer School for Seniors). Ezerzeme, No. 56 (9155), pp. 1-2.

49. Trede, L. (2017a). Sporta diena 2017 (Sports Day 2017). Neatkarigas Tukuma zinas. No. 112 (2585), p. 5

50. Vilnitis, J. (2017). "Latvenergo" atradis domubiedru Jurmalas dome (Latvenergo Has Found an Ally in Jurmala City Council). Jurmalas vards, No. 27 (208), pp. 1-2.

51.Zdanovska, N. (2017). "Mes atradam viena otru" ("We Found Each Other"). Ezerzeme, No. 88 (9187), p. 5.

52. Zelce, V. (2006). Lokala prese - kopienas informacijas vides veidotaja (Local Press - the Shaper of the Community Information Environment). In I. Brikse (red.), Informacijas vide Latvija: 21. gadsimta sakums (Information environment in Latvia: The beginning of the 21st century). Riga: Zinatne, pp. 144-166.

53. Zinu dienests (2017a). Nosledzies Kemeru dabas turisma centra un parka labiekartojuma metu konkurss (The Sketch Contest on the Development of Kemeri Nature Tourism Centre and Park Has Concluded). Jurmalas vards, No. 41 (222), p. 6.

54. Zinu dienests (2017b). Rehabilitacijas centram "Jaunkemeri" -50 ! ( $50^{\text {th }}$ Anniversary for the Rehabilitation Center "Jaunkemeri"!). Jurmalas vards, No. 30 (211), p. 1, 12. 